\title{
Quinoxaline Moiety: A Potential Scaffold against Mycobacterium tuberculosis
}

\author{
Marc Montana ${ }^{1,2}$, Vincent Montero ${ }^{1}$, Omar Khoumeri ${ }^{1}$ and Patrice Vanelle ${ }^{1,3, *}$ \\ 1 Aix Marseille Univ, CNRS, ICR, Equipe Pharmaco-Chimie Radicalaire, Faculté de Pharmacie, \\ 13005 Marseille, France; marc.montana@univ-amu.fr (M.M.); vincent.montero@univ-amu.fr (V.M.); \\ omar.khoumeri@univ-amu.fr (O.K.) \\ 2 Assistance Publique-Hôpitaux de Marseille (AP-HM), Oncopharma, 13015 Marseille, France \\ 3 Assistance Publique-Hôpitaux de Marseille (AP-HM), Service Central de la Qualité et de l'Information \\ Pharmaceutiques (SCQIP), 13005 Marseille, France \\ * Correspondence: patrice.vanelle@univ-amu.fr; Tel.: +33-4-91-83-55-80; Fax: +33-4-91-79-46-77
}

Citation: Montana, M.; Montero, V.; Khoumeri, O.; Vanelle, P. Quinoxaline Moiety: A Potential Scaffold against Mycobacterium tuberculosis. Molecules 2021, 26, 4742. https://doi.org/ $10.3390 /$ molecules 26164742

Academic Editors: Jonathan Sellars, Alistair Brown and Jean-Marc Sabatier

Received: 11 June 2021

Accepted: 3 August 2021

Published: 5 August 2021

Publisher's Note: MDPI stays neutral with regard to jurisdictional claims in published maps and institutional affiliations.

Copyright: (c) 2021 by the authors. Licensee MDPI, Basel, Switzerland. This article is an open access article distributed under the terms and conditions of the Creative Commons Attribution (CC BY) license (https:// creativecommons.org/licenses/by/ $4.0 /)$.

\begin{abstract}
Background. The past decades have seen numerous efforts to develop new antitubercular agents. Currently, the available regimens are lengthy, only partially effective, and associated with high rates of adverse events. The challenge is therefore to develop new agents with faster and more efficient action. The versatile quinoxaline ring possesses a broad spectrum of pharmacological activities, ensuring considerable attention to it in the field of medicinal chemistry. Objectives. In continuation of our program on the pharmacological activity of quinoxaline derivatives, this review focuses on potential antimycobacterial activity of recent quinoxaline derivatives and discusses their structure-activity relationship for designing new analogs with improved activity. Methods. The review compiles recent studies published between January 2011 and April 2021. Results. The final total of 23 studies were examined. Conclusions. Data from studies of quinoxaline and quinoxaline 1,4-di-N-oxide derivatives highlight that specific derivatives show encouraging perspectives in the treatment of Mycobacterium tuberculosis and the recent growing interest for these scaffolds. These interesting results warrant further investigation, which may allow identification of novel antitubercular candidates based on this scaffold.
\end{abstract}

Keywords: quinoxaline; Mycobacterium; tuberculosis; SAR; biological applications; chemistry

\section{Introduction}

In 2020, the World Health Organization estimated that about 10 million people (range: 8.9-11.0 million) contracted tuberculosis (TB) in 2019, which was responsible for 1.4 million deaths [1]. Treatment of drug-susceptible active tuberculosis consists of a standard 6-month regimen of four antimicrobials (usually isoniazid, rifampin, pyrazinamide, and ethambutol) $[2,3]$. However, these regimens are lengthy, only partially effective, and associated with high rates of adverse events. The challenge is therefore to develop new agents with faster and more efficient action.

Nitrogen-containing heterocycles are of particular interest for the development of new drugs or novel potential lead molecules [4-8]. Quinoxaline, formed by the fusion of two aromatic rings, benzene and pyrazine, is one of the heterocycles receiving the most attention.

The versatile quinoxaline ring possesses a broad spectrum of pharmacological activities (antiviral [9], anticancer [10], antileishmanial [11]), ensuring considerable attention to it in the field of medicinal chemistry [12]. In addition, as quinoxaline is also a part of well-known wide-spectrum antibiotics echinomycin, levomycin, and actinoleutin, quinoxaline derivatives are expected to have antimycobacterial activity. One of them, clofazimine, initially known as B663, is currently under intensive clinical investigation for the treatment 
of drug-resistant TB to assess the compound's treatment outcomes with multidrug-resistant and extensively drug-resistant TB (Figure 1).<smiles>CC(C)/N=c1/cc2n(-c3ccc(Cl)cc3)c3ccccc3nc-2cc1Nc1ccc(Cl)cc1</smiles>

Figure 1. Chemical structure of clofazimine.

Some quinoxaline-1,4-di- $\mathrm{N}$-oxide derivatives have also shown excellent antimicrobial activities against Mycobacterium tuberculosis [13-15], indicating the great interest of these types of structure for the development of new structural classes of anti-TB drugs. The oxidation of nitrogen in a quinoxaline ring has a pronounced effect on antimycobacterial activity [16]. In addition, quinoxaline 1,4-di- $\mathrm{N}$-oxides are species that suffer a bioreductive process under the hypoxic conditions [17] found in tuberculous granulomas, where nonreplicating persistent forms of Mycobacterium tuberculosis bacilli can survive, leading to the need for long treatments and the risk of treatment resistance [13]. In continuation of our program on the pharmacological activity of quinoxaline derivatives, we decided to focus on the development of new quinoxalines and quinoxaline 1,4-di- $\mathrm{N}$-oxide derivatives as antitubercular drugs. This review compiles studies published between 2011 and 2021 and discusses the potential antimycobacterial activity of recent quinoxaline derivatives.

\section{Methods}

\subsection{Data Sources and Searches}

The research was conducted using three databases: MEDLINE/PubMed, Web of Science, and Science Direct Elsevier (Table 1).

Table 1. Data sources and searches.

\begin{tabular}{|c|c|c|c|c|c|}
\hline Site & Keyword 1 & $\begin{array}{l}\text { Boolean } \\
\text { Operator }\end{array}$ & Keyword 2 & Date & Filter \\
\hline $\begin{array}{c}\text { MEDLINE/PubMed } \\
\text { (National Library of } \\
\text { Medicine-www.ncbi.nlm. } \\
\text { nih.gov/pubmed } \\
\text { (accessed on 13 April 2021) }\end{array}$ & Quinoxaline & AND & Tuberculosis & $\begin{array}{l}\text { 01 January } \\
\text { 2011-01 April } \\
2021\end{array}$ & $\begin{array}{l}\text { Document type: } \\
\text { journal articles }\end{array}$ \\
\hline $\begin{array}{l}\text { Web of Science (Thomson } \\
\text { Reuters Scientific-www. } \\
\text { webofknowledge.com } \\
\text { (accessed on } 13 \text { April 2021) }\end{array}$ & $\begin{array}{l}\text { Quinoxaline } \\
\text { (topic) }\end{array}$ & AND & $\begin{array}{l}\text { Tuberculosis } \\
\text { (Topic) }\end{array}$ & 2011-2021 & $\begin{array}{c}\text { Document type: } \\
\text { only articles }\end{array}$ \\
\hline $\begin{array}{l}\text { Science Direct Elsevier } \\
\text { (www.sciencedirect.com } \\
\text { (accessed on } 13 \text { April 2021) }\end{array}$ & Quinoxaline & AND & Tuberculosis & 2011-2021 & $\begin{array}{l}\text { Document type: } \\
\text { only research } \\
\text { articles }\end{array}$ \\
\hline
\end{tabular}




\subsection{Study Selection}

The review was performed by two independent reviewers as described by PRISMA [18]. Eligibility criteria were predetermined by the authors (Table 2).

Table 2. Inclusion and exclusion criteria.

\begin{tabular}{cccc}
\hline & Parameter & Inclusion & Exclusion \\
\hline 1 & Language & French, English & Any other language \\
2 & Type of study & In vitro and/or in vivo studies, & Articles that focus only on synthesis or other \\
purely chemical parameters \\
3 & Type of publication & biological activity & Book chapters, posters, reviews \\
4 & Search terms & & Merely citing keywords in the text \\
\hline
\end{tabular}

In the first step, duplicates were eliminated. Then, articles' titles and abstracts were evaluated according to the inclusion criteria. The authors read each selected full text and eliminated articles fitting the exclusion criteria. During this stage, the references of the relevant articles were examined to identify additional studies not retrieved in computerized databases.

\section{Results}

The database search identified 148 records; 27 repeated files were discarded, leaving 121 articles.

After the evaluation phase (title/abstract) and full-text reading, 98 records were excluded. The final total of 23 studies were included in this review. No other paper was added from the reference lists of the identified studies.

During the 2011-2015 and the 2016-2021 periods, six articles (two concerning 1,4-di-Noxide-quinoxaline derivatives and four concerning quinoxaline derivatives) and 17 articles (six concerning 1,4-di- $N$-oxide-quinoxaline derivatives and 11 concerning quinoxaline derivatives) were published, respectively.

\section{Discussion}

\subsection{Quinoxaline Derivatives as Antimycobacterial Agents}

A wide variety of methods for the synthesis of functionalized quinoxalines have already been reported in the literature. In general, quinoxaline derivatives are obtained either by condensation of $o$-phenylenediamine and its derivatives with a dicarbonyl compound under conventional conditions or reaction of 1,2-diaza-1,3-butadienes with 1,2-diamines [19-22]. Eco-friendly approaches using recyclable catalysts [23,24], oxidative cyclisation of 1,2-diamines and phenacyl bromides [25], microwave-assisted synthesis [26,27], reactions in aqueous medium [28], or one-pot synthesis [29] have also been described.

\subsubsection{Tricyclic Quinoxaline Derivatives}

Between 2017 and 2020, three series of original benzo[g]quinoxaline-5,10-dione derivatives were synthesized using a multistep synthetic route from 2,3-dihydroxynaphtalene and evaluated as potential antimycobacterial agents [30-32] (Figure 2).

Thirteen novel compounds belonging to the pyridine series, 11 new pyrazoline derivatives, and 11 7-[3-(substituted) phenylprop-2-enoyl]quinoxaline derivatives were obtained; they displayed moderate antimycobacterial activity [30-32] (Table 3). 
<smiles>[R]c1ccc(-c2cc(-c3ccc4c(c3)C(=O)C3N=C(c5ccccc5)C(c5ccccc5)=NC3C4=O)nc(N)c2C#N)cc1</smiles><smiles>[R]c1ccc(C2CC(c3ccc4c(c3)C(=O)C3N=C(c5ccccc5)C(c5ccccc5)=NC3C4=O)=NN2)cc1</smiles><smiles>[R]c1ccc(/C=C/C(=O)c2ccc3c(c2)C(=O)C2N=C(c4ccccc4)C(c4ccccc4)=NC2C3=O)cc1</smiles>

Figure 2. Chemical structures of new series benzo[g]quinoxaline-5,10-dione derivatives.

Pyrroloquinoxaline moiety represents a very attractive scaffold in medicinal chemistry for its biological anti-infectious properties, including antimycobacterial activity [33]. This, pyrrolo[1,2-a]quinoxaline was chosen as scaffold and led to the synthesis of 23 new pyrrolo[1,2-a]quinoxaline derivatives (Figure 3) that displayed very encouraging antimycobacterial activity [34].

Ten compounds showed both interesting antimycobacterial activity and moderate cytotoxicity. Antimycobacterial activity was observed to depend on varying chemical characteristics, like the replacement of tertiary nitrogen by an NH group, leading to compounds 7-10 with improved solubility and the lowest minimal inhibitory concentration (MIC) value $(5 \mu \mathrm{g} / \mathrm{mL})$ (Table 4$)$.

Modification of the linker between $\mathrm{R}_{2}$ and pyrrolo[1,2-a]quinoxaline moiety led to a minor variation in antibacterial activity, although substitutions at the $R_{2}$ position with an aromatic group led to the most active compounds (Figure 4). Derivative N-((7-chloro-1-(2fluorophenyl)pyrrolo[1,2-a]quinoxalin-3-yl)methyl)-2-(3,4-dimethoxyphenyl)ethanamine (9) was identified as offering the best oral bioavailability. Determination of enzyme inhibition and molecular docking studies revealed that these original derivatives could act by targeting the classic anti-TB drug target InhA by forming $\mathrm{H}$ bonds as well as Pi-Pi interactions.

In addition, several novel 4,5-dihydropyrrolo[1,2-a]quinoxalines and pyrrolo[1,2a]quinoxaline-2-ones were synthesized from the reaction between 2-(1H-pyrrol-1-yl)anilines and imidazo[1,2-a]pyridine-3-carbaldehyde or isatin and are of current interest as antimycobacterial agents [35] (Figure 5).

Five 4-substitued 4,5-dihydropyrrolo[1,2-a]quinoxalines and only one pyrrolo[1,2a]quinoxaline-2-one derivative displayed potent antimycobacterial activity, with MIC ranging from 6.25 to $12.5 \mu \mathrm{g} / \mathrm{mL}$. However, no clear structure-activity relationship could be demonstrated from the small number of synthesized compounds [35]. 
Table 3. Chemical structure, minimal inhibitory concentration (MIC) values against Mycobacterium tuberculosis [30-32].

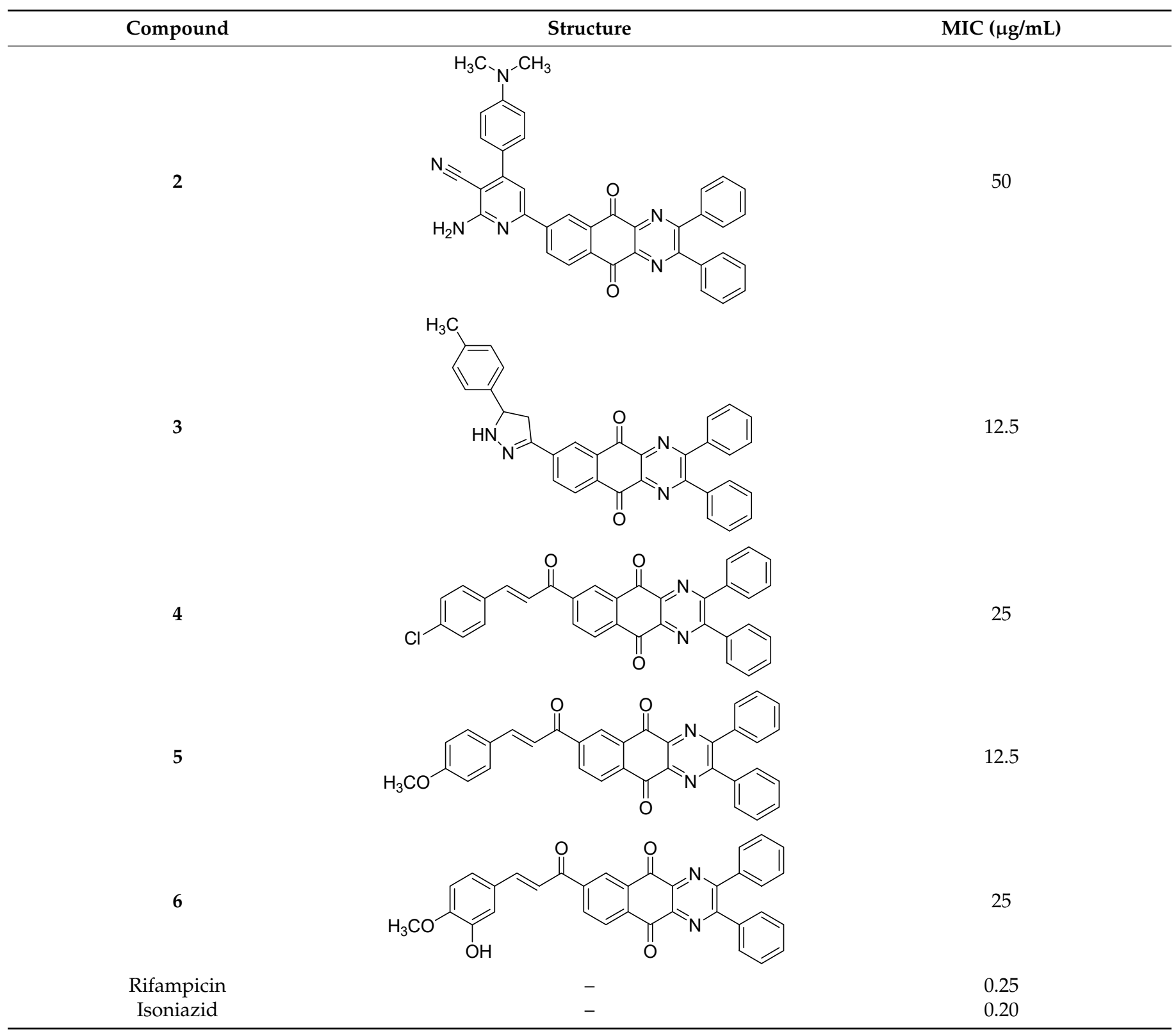

\subsubsection{Hybrids and Conjugates}

Many classes of organic compounds have previously been evaluated for their antimycobacterial activity. A rational design strategy based on combining the biological properties of different bioactive structures into a single compound could lead to new compounds with increased activity, combined modes of action, or improved tolerance profiles compared to parent structures.

Then, the quinoxaline ring fused with azetidinone and thiazolidinone, two structural scaffolds possessing antitubercular activity [36-38], showed in vitro activity against Mycobacterium tuberculosis. Quinoxaline derivatives with 2-chloro, dimethylamino and nitro substitution showed comparable activity to that of isoniazid (MIC $=0.67-0.97 \mu \mathrm{g} / \mathrm{mL}$ versus $0.46 \mu \mathrm{g} / \mathrm{mL}$ ) [39] (Figure 6). 
<smiles>[R][X]C1CCN(Cc2cc(-c3ccccc3F)n3c2cnc2cc([R])ccc23)CC1</smiles>

$X=N, O$
$R_{1}=H, C l$
$R_{2}=H$,

$3-\mathrm{CF}_{3}-\mathrm{Ph}$,

$\mathrm{CH}_{3}$,

$\mathrm{C}_{6} \mathrm{H}_{5}$

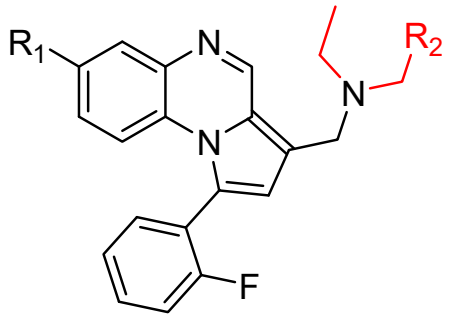

$\mathrm{R}_{1}=\mathrm{H}, \mathrm{Cl}$

$\mathrm{R}_{2}=\mathrm{H}$,

$3-\mathrm{CF}_{3}-\mathrm{Ph}$,

$\mathrm{CH}_{3}$,

$\mathrm{C}_{6} \mathrm{H}_{5}$

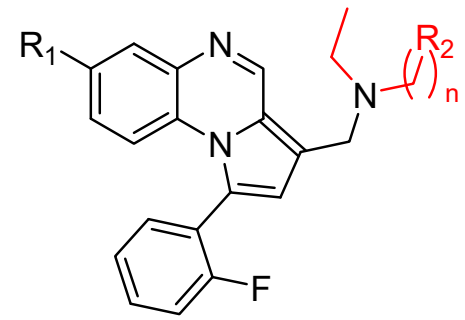

$\mathrm{n}=1,2,3$

$\mathrm{R}_{1}=\mathrm{H}, \mathrm{Cl}, \mathrm{F}, \mathrm{Br}$

$\mathrm{R}_{2}=\mathrm{CH}_{3}$,

$\mathrm{C}_{6} \mathrm{H}_{5}$,

$\left(\mathrm{CH}_{3}\right)_{2}$

2-Cl-6-F-Ph

4-Br-Ph

$3,4-\mathrm{OCH}_{3}-\mathrm{Ph}$

Figure 3. Chemical structures of new series of pyrrolo[1,2-a]quinoxaline derivatives.

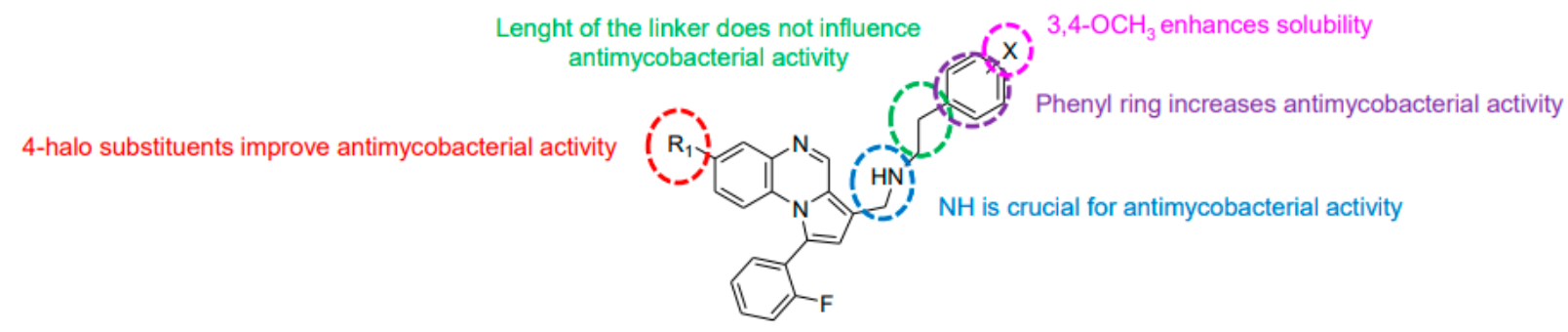

Figure 4. Structure-activity relationship of novel quinoxaline derivatives with antimycobacterial activity.<smiles>[R]c1ccc(-c2nc3ccc([R])cn3c2C2Nc3ccccc3-n3cccc32)cc1</smiles><smiles>[R2]c1ccc2c(c1)-n1cccc1C1(N2)C(=O)N([R])c2ccc([R])cc21</smiles>

$$
\begin{aligned}
& \mathrm{R}_{1}=\mathrm{H}, \mathrm{Cl}, \mathrm{CH}_{3} \\
& \mathrm{R}_{2}=2-\mathrm{Br}, 4-\mathrm{Cl}, 4-\mathrm{CH}_{3}
\end{aligned}
$$$$
\mathrm{R}_{1}=\mathrm{H}, \mathrm{F}
$$

$$
\begin{aligned}
& \mathrm{R}_{2}=\mathrm{H}, \mathrm{Cl}, \mathrm{F}, \mathrm{I}, \mathrm{CH}_{3}, \mathrm{OCF}_{3} \\
& \mathrm{R}_{3}=\mathrm{H}, \mathrm{CH}_{3}, \mathrm{CH}_{2}-\mathrm{Ph}
\end{aligned}
$$

Figure 5. General structure of novel 4,5-dihydropyrrolo[1,2-a]quinoxalines and pyrrolo[1,2a]quinoxaline-2-ones synthesized. 
Table 4. Chemical structure and MIC values against Mycobacterium tuberculosis of the best candidates from pyrrolo[1,2-a]quinoxaline series.

7<smiles>Fc1ccccc1-c1cc(CNCc2ccccc2)c2cnc3cc(Cl)ccc3n12</smiles>

8<smiles>Fc1ccccc1-c1cc(CNCCc2ccc(Br)cc2)c2cnc3cc(Cl)ccc3n12</smiles>

9<smiles>COc1ccc(CCNCc2cc(-c3ccccc3F)n3c2cnc2cc(Cl)ccc23)cc1OC</smiles>

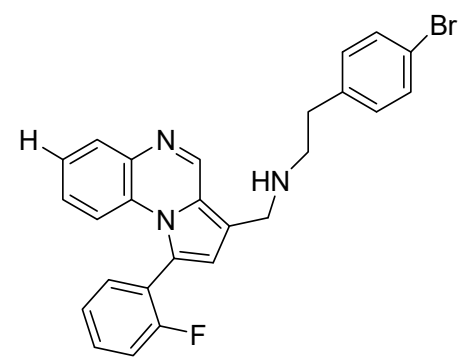

As vitamin B6 is an important cofactor in a large number of important enzymic reactions and is also used in bioinorganic chemistry as a ligand, a new series of 13 quinoxalines bearing the pyridoxal moiety was synthesized and tested against Mycobacterium tuberculosis (Figure 7). In a hydrazone series, the 7-chloroquinoxaline derivative (11) showed the best activity, with the MIC of $72.72 \mu \mathrm{M}$. The number of nitrogen and chlorine atoms in the radical moiety plays an important role in antimycobacterial activity [40]. 
<smiles>[R]C1C(Cl)C(=O)N1c1ccccc1/N=c1\[nH]c2ccccc2[nH]\c1=N/c1ccccc1</smiles>

$$
\begin{array}{ll}
\mathrm{R}: \text { 4- } \mathrm{CH}_{3}-\mathrm{Ph} & 4-\mathrm{OH}-3-\mathrm{OCH}_{3}-\mathrm{Ph} \\
4-\mathrm{OH}-\mathrm{Ph} & 2-\mathrm{OH}-\mathrm{Ph} \\
4-\mathrm{OCH}_{3}-\mathrm{Ph} & 3-\mathrm{NO}_{2}-\mathrm{Ph} \\
4-\mathrm{Cl}-\mathrm{Ph} & 2-\mathrm{Cl}-\mathrm{Ph} \\
4-\left(\mathrm{CH}_{3}\right)_{2} \mathrm{~N}-\mathrm{Ph} & \text { furanyl }
\end{array}
$$

Figure 6. General structure of original quinoxaline derivatives containing azetidinone and thiazolidinone moieties.<smiles>Cc1ncc(CO)c(/C=N/Nc2cnc3cc(Cl)ccc3n2)c1O</smiles>

Figure 7. Lead compound of hydrazones and $N$-acylhydrazones containing vitamin B6 and different heteroaromatic nuclei.

In order to prevent excessive toxicity due to high lipophilicity and considering the biosafety profile of sugar conjugates [41-43], some new sugar conjugates of quinoxaline were synthesized and evaluated for their antitubercular activity. Of a series of six sugar conjugates of quinoxaline compounds, all the synthesized derivatives demonstrated interesting antimycobacterial activity, with the MIC ranging from 0.65 to $9.6 \mu \mathrm{M} \mathrm{[43]} \mathrm{(Figure} \mathrm{8).}$<smiles>O=c1[nH]c2ccccc2[nH]c1=O</smiles>

12

\section{$\mathrm{NH}_{2} \mathrm{NH}_{2}$}<smiles>N/N=c1/[nH]c2ccccc2[nH]c1=O</smiles>

13

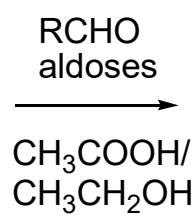

$$
\begin{aligned}
\text { Ose }=\text { glucose: } 13 \mathbf{a} \\
\text { mannose: } 13 \mathbf{b} \\
\text { maltose: } 13 \mathbf{c} \\
\text { lactose: } 13 \mathbf{d} \\
\text { ribose: } 13 \mathrm{e} \\
\text { xylose: } 13 \mathrm{f}
\end{aligned}
$$

Figure 8. Schematic route for the synthesis of sugar conjugates of quinoxaline. 
The ribose conjugate (13e) exhibited the best antimycobacterial activity, with the $\mathrm{MIC}=0.65 \mu \mathrm{M}$. All the sugar conjugates were more active than the initial quinoxaline2,3- $(1 H, 4 H)$-dione and the intermediate 3-hydrazono-3,4-dihydroquinoxalin-2(1H)-one at the MIC $>59.2 \mu \mathrm{M}$ and the MIC $=27.2 \mu \mathrm{M}$, respectively. The structure-activity relationship showed that monosaccharides had better activity than disaccharides and that the aldopentoses were more potent than the aldohexoses. As in silico docking analysis revealed that these compounds could interact with DNA gyrase, it was concluded that the stereoisomerism of sugar may influence antimycobacterial activity; this was supported by the fact that the ribose derivative was seven times more potent than the xylose derivative.

Chalcones are compounds with a wide range of biological activities, including antitubercular activity $[44,45]$. Of a series of 14 original quinoxalinyl chalcones, two derivatives demonstrated equivalent activity to pyrazinamide and ciprofloxacin taken as reference with the MIC $=3.12 \mu \mathrm{g} / \mathrm{mL}$. The structure-activity relationship showed that the presence of a hydroxyl substituent at position 3 on the phenyl ring increases antimycobacterial activity. Replacing phenyl with naphthyl resulted in reduced antimycobacterial activity, indicating that the hydrophobicity/lipophilicity balance plays an important role in these derivatives' activity [46] (Table 5).

The efficacy of quinoxaline-derived chalcones has recently been confirmed by the preclinical evaluation of a new series of derivatives. Of the synthesized compounds, six molecules inhibited Mycobacterium tuberculosis growth, with the MIC ranging from 3.13 to $12.5 \mu \mathrm{g} / \mathrm{mL}$ [47]. Further investigations on the lead compound (20) also demonstrated that this derivative exhibited synergistic effect with moxifloxacin and did not cause mutagenicity or genotoxicity (Table 6).

In addition, the modification of nalidixic acid, a representative of the quinolone and fluoroquinolone antibiotics which are an essential component of treatment strategies for drug-resistant TB [1], on its - $\mathrm{COOH}$ group led to the formation of original quinoxaline conjugates which showed encouraging antimycobacterial activity. Among the synthesized derivatives, quinoxalines with azide as side chain (25 and 26) exhibited the two best activities, with the percentage of inhibition of Mycobacterium tuberculosis at $6.25 \mu \mathrm{g} / \mathrm{mL}$ of $93 \%$ and $91 \%$, respectively, compared to $100 \%$ for ciprofloxacin taken as reference [48] (Figure 9).

As Schiff bases possess antimicrobial and antitubercular properties [49], synthesis of some quinoxaline-incorporated Schiff bases was performed. Among an original series of ten different Schiff bases resulting from the reaction between 2-((3-methylquinoxalin-2yl)oxy)acetohydrazide (31) and various heterocyclic/aromatic aldehydes, five compounds exhibited potent antitubercular activity [49] (Figure 10).<smiles>CCn1cc(C(=O)NNC(=S)/N=c2\[nH]c3ccccc3[nH]c2=O)c(=O)c2ccc(C)nc21</smiles>

25<smiles>CCn1cc(C(=O)N/N=c2/[nH]c3ccccc3[nH]c2=O)c(=O)c2ccc(C)nc21</smiles>

Figure 9. Chemical structures of lead compounds in nalidixic acid series. 
Table 5. Chemical structure of some quinoxalinyl chalcones and their MIC values against Mycobacterium tuberculosis.

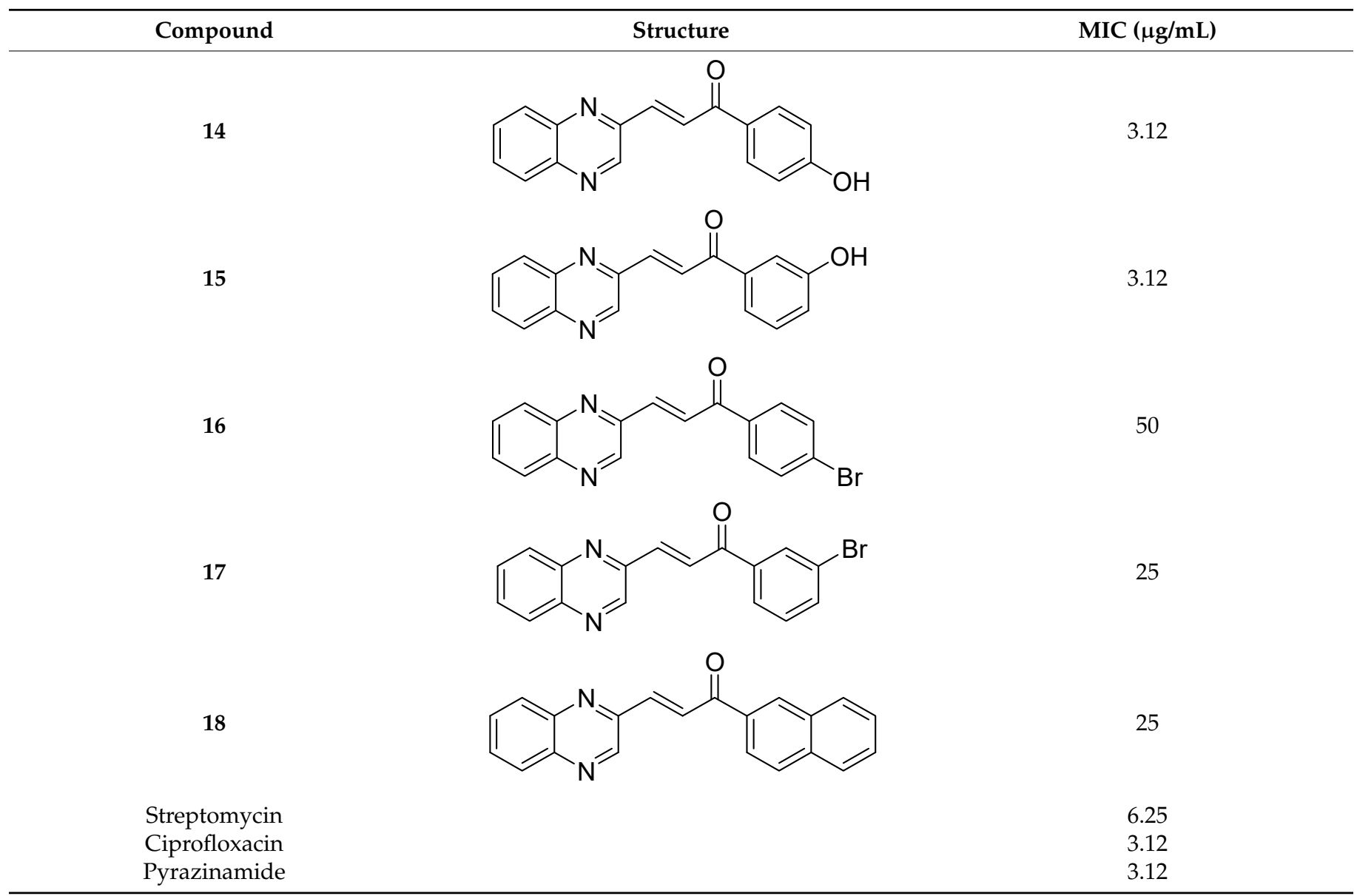<smiles>COc1nc2ccccc2nc1C</smiles>

27<smiles>CCNNNC(=O)COc1nc2ccccc2nc1C</smiles>

27a: $\mathrm{Ar}=\mathrm{C}_{6} \mathrm{H}_{5}$

27b: $\mathrm{Ar}=4-\mathrm{Cl}-\mathrm{Ph} \mathrm{C}$

27c: $\mathrm{Ar}=3-\mathrm{NO}_{2}-\mathrm{Ph}$

27d: $\mathrm{Ar}=4-\mathrm{OH}-\mathrm{Ph}$.

27e: $\mathrm{Ar}=3,4^{-}\left(\mathrm{OCH}_{3}\right)_{2}-\mathrm{Ph}$

27f: $\mathrm{Ar}=4-\mathrm{OCH}_{3}-\mathrm{Ph}$

27g: $\mathrm{Ar}=4-\mathrm{N}(\mathrm{CH})_{2}-\mathrm{Ph} 2$

27h: $\mathrm{Ar}=3$-indoyl

27i: Ar = 2-furyl

27j: 5-(4-nitrophenyl)-2-furfuryl

Rifampicin
$\%$ inhibition at MIC $6.25 \mu \mathrm{g} / \mathrm{mL}=23$

$\%$ inhibition at MIC $6.25 \mu \mathrm{g} / \mathrm{mL}=15$

$\%$ inhibition at MIC $6.25 \mu \mathrm{g} / \mathrm{mL}=6$

$\%$ inhibition at MIC $6.25 \mu \mathrm{g} / \mathrm{mL}=58$

$\%$ inhibition at MIC $6.25 \mu \mathrm{g} / \mathrm{mL}=25$

$\%$ inhibition at MIC $6.25 \mu \mathrm{g} / \mathrm{mL}=10$

$\%$ inhibition at MIC $6.25 \mu \mathrm{g} / \mathrm{mL}=32$

$\%$ inhibition at MIC $6.25 \mu \mathrm{g} / \mathrm{mL}=7$

$\%$ inhibition at MIC $6.25 \mu \mathrm{g} / \mathrm{mL}=56$

$\%$ inhibition at MIC $6.25 \mu \mathrm{g} / \mathrm{mL}=50$

$\%$ inhibition at MIC $6.25 \mu \mathrm{g} / \mathrm{mL}=95$

Figure 10. Percentage of inhibition of quinoxaline-incorporated Schiff bases against Mycobacterium tuberculosis. 
Table 6. MIC values against Mycobacterium tuberculosis of quinoxaline-derived chalcones.

\begin{tabular}{|c|c|c|}
\hline Compound & Structure & $\operatorname{MIC}(\mu \mathrm{g} / \mathrm{mL})$ \\
\hline 19 & & 12.5 \\
\hline 20 & & 3.13 \\
\hline 21 & & 12.5 \\
\hline 22 & & 6.25 \\
\hline 23 & & 12.5 \\
\hline 24 & & 5 \\
\hline Rifampicin & & $<0.2$ \\
\hline Moxifloxacin & & $<0.2$ \\
\hline Isoniazid & & 0.39 \\
\hline
\end{tabular}

Finally, spiroheterocyclic structures are well known for their antimycobacterial properties $[50,51]$. Spiropyrrolidine tethered indenoquinoxaline heterocyclic hybrids were synthesized and evaluated against Mycobacterium tuberculosis. Of the 11 synthesized compounds, bearing $m$-nitro, $p$-bromo and $o$-chloro substituents on the aryl ring showed interesting antimycobacterial activity, with MIC values ranging from 1.56 to $6.25 \mu \mathrm{g} / \mathrm{mL}$ [52] (Table 7).

\subsubsection{Other Structures}

Several derivatives of 2-substituted quinoxalines have also shown interesting antitubercular activities. Thus, quinoxaline alkynyl derivatives demonstrated antimycobacterial activity. Of the 19 original quinoxalines bearing diverse substituents on the alkynyl group synthesized from quinoxaline-2-ol derivatives, seven compounds had $\mathrm{MIC}_{90}<10 \mu \mathrm{M}$ and five compounds had $\mathrm{MIC}_{90}$ ranging from 10 to $20 \mu \mathrm{M}$ [53] (Table 8). 
Table 7. Chemical structure of some spiropyrrolidine tethered indenoquinoxaline heterocyclic hybrids and their MIC values against Mycobacterium tuberculosis.

\begin{tabular}{|c|c|c|}
\hline Compound & Structure & $\operatorname{MIC}(\mu \mathrm{g} / \mathrm{mL})$ \\
\hline 28 & & 3.125 \\
\hline 29 & & 6.25 \\
\hline 30 & & 12.5 \\
\hline 31 & & 1.56 \\
\hline Ethambutol & & 1.56 \\
\hline Rifampicin & & 0.1 \\
\hline Isoniazid & & 0.05 \\
\hline
\end{tabular}

The presence of an electron-withdrawing group at the $\mathrm{C} 6$ position of the quinoxaline moiety plays an important role in antimycobacterial activity: four of the most active compounds are derivatives bearing $\mathrm{NO}_{2}$ at this position with $\mathrm{MIC}_{90}<3 \mu \mathrm{M}$.

Moreover, screening of a library of compounds identified three original 2-carboxyquinoxaline compounds showing activity against Mycobacterium tuberculosis with $\mathrm{MIC}_{99}$ values ranging from 3.1 to $12.5 \mu \mathrm{M}$ [54]. Among them, the lead compound (39) which exhibited a MIC 99 of $3.1 \mu \mathrm{M}$ was shown to noncovalently and noncompetitively inhibit DprE1, an enzyme essential for bacterial wall synthesis by forming hydrophobic interactions and hydrogen bonds (Figure 11). 
Table 8. Chemical structure and MIC values against Mycobacterium tuberculosis of the best candidates from the quinoxaline alkynyl series.

Compound<smiles>COc1ccc(CNc2nc3cc(C(F)(F)F)ccc3nc2C(=O)O)cc1</smiles>

Figure 11. Structure of the lead compound 3-((4-methoxybenzyl)amino)-6-(trifluoromethyl) quinoxaline-2-carboxylic acid, a new DprE1 inhibitor. 


\subsection{Quinoxaline-1,4-di-N-oxide Derivatives Active against Mycobacterium tuberculosis}

Quinoxaline-1,4-di- $\mathrm{N}$-oxide derivatives are a class of compounds with a variety of biological properties, including antitumor, anti-inflammatory, and anti-infectious activity [2]. The classic method of quinoxaline-1,4-di- $\mathrm{N}$-oxide preparation uses benzofuroxane $\mathrm{N}$-oxide as the reagent [55].

\subsubsection{Hybrids and Conjugates}

1,2,3-triazole and their derivatives are known for their various biological activities including antifungal and antibacterial activity [56]. In order to study the influence of the substitution at the $\mathrm{C} 2$ position in quinoxaline-1,4-di- $\mathrm{N}$-oxide series, thirtyone 1,2,3-triazole analogs of quinoxaline-1,4-di- $\mathrm{N}$-oxide were synthesized and evaluated against Mycobacterium tuberculosis, yielding 16 compounds with the MIC ranging from 12.5 to $25 \mu \mathrm{g} / \mathrm{mL}$ [56] (Figure 12).

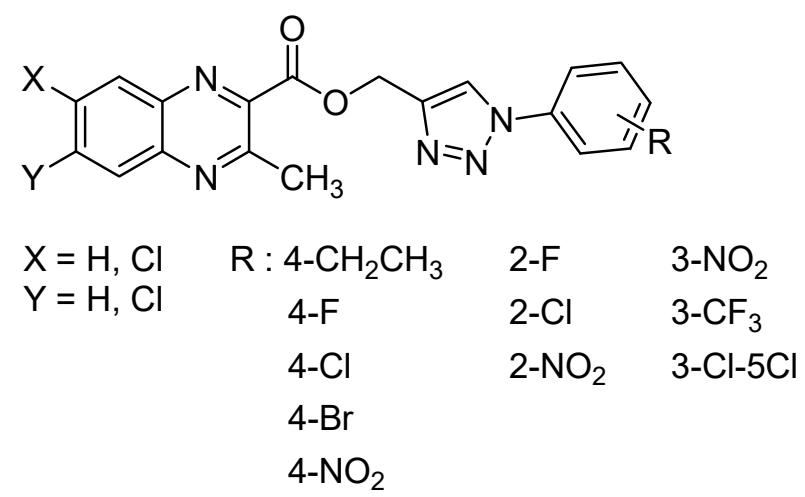

Figure 12. General structure of 1,2,3-triazole analogs of quinoxaline-1,4-di- $N$-oxide.

More specifically, in 2-(((1-(substituted phenyl)-1H-1,2,3-triazol-4-yl)methoxy)carbonyl)3-methylquinoxaline-1,4-dioxide series, only 2-chloro and 2- or 3-nitro compounds exhibited high activity. In 3-(((1-(substituted phenyl)-1H-1,2,3-triazol-4-yl)methoxy)carbonyl)-6chloro-2-methylquinoxaline-1,4-dioxide series, unsubstituted, ortho-, and para-substituted derivatives exhibited high activity. The most active compound of the three series, 6-chloro2-methyl-3-(((1-phenyl-1H-1,2,3-triazol-4-yl)methoxy)carbonyl)quinoxaline-1,4-dioxide, exhibited good antimycobacterial activity, with the MIC of $12.5 \mu \mathrm{g} / \mathrm{mL}$ against the tested strains versus $3.1 \mu \mathrm{g} / \mathrm{mL}$ for reference drug isoniazid. In the $2-(((1-$ (substituted phenyl)- $1 H$ 1,2,3-triazol-4-yl)methoxy)carbonyl)-6,7-dichloro-3-methylquinoxaline-1,4-dioxide series, only para-substituted halogen compounds exhibited activity. These structure-activity relationships also demonstrated that the introduction of an electron-withdrawing group resulted in less active compounds.

In addition, hybridization of quinoxaline 1,4-di- $\mathrm{N}$-oxide with chalcone, fluoroquinolone, and thiazolidinone scaffolds was investigated $[57,58]$. Of the 10 original chalcones newly synthesized by Claisen-Schmidt condensation, only one displayed potency, with the MIC $=3.1 \mu \mathrm{M}$ compared to $6.2 \mu \mathrm{M}, 0.3 \mu \mathrm{M}$, and $0.04 \mu \mathrm{M}$, respectively, for ethambutol, isoniazid, and rifampicin taken as reference. In this same study, four of the five most potent derivatives were fluoroquinolone analogs, with MIC values ranging from 1.6 to $3.1 \mu \mathrm{M}$ (Table 9). The structure-activity relationship showed that the presence of an electronwithdrawing substituent like a halogen atom at position $\mathrm{C} 6$ or $\mathrm{C} 7$ of the quinoxaline moiety enhances the activity. In addition, the presence of $\mathrm{CF}_{3}$ at position $\mathrm{C} 3$ promotes antimycobacterial activity, while the nature of the lateral side chain substituent at the $\mathrm{C} 2$ position of the quinoxaline group seems to have less influence on biological activity [57]. 
Table 9. Antimycobacterial activity of quinoxaline derivatives based on molecular hybridization of quinoxaline 1,4-di- $N$ oxide with the chalcone and fluoroquinolone scaffolds.

40<smiles>Cc1c(C(=O)/C=C/c2ccccc2)[n+]([O-])c2cc(Cl)ccc2[n+]1[O-]</smiles>

41<smiles>O=C(c1ccco1)c1c(C(F)(F)F)[n+](O)c2cc(N3CCOCC3)c(Cl)cc2[n+]1O</smiles>

42<smiles>CC(=O)C1=C(C(F)(F)F)N([O])c2cc(F)c(N3CCCCC3)cc2[N+]1[O]</smiles><smiles>COC(=O)C1=C(C(F)(F)F)N([O])c2ccc(N3CCN(c4ccc(F)cc4)CC3)cc2[N+]1[O]</smiles>

44<smiles>[2H][n+]1c(C(F)(F)F)c(C(C)=O)[n+]([O])c2cc(N3CCSCC3)c(F)cc21</smiles>

In thiazolidinone series, out of 26 novel derivatives, four compounds displayed potent antimycobacterial activity, four compounds-moderate activity [58] (Table 10). The presence of an electron-withdrawing group at the para position of the phenyl group is essential for higher activity and the presence of a halogen atom at position C7 of the quinoxaline nucleus increases antimycobacterial activity. Replacement of halogen atoms with a methyl or methoxy resulted in decreased antimycobacterial activity. 
Table 10. Antimycobacterial activity of quinoxaline derivatives based on molecular hybridization of quinoxaline 1,4-di- $N$ oxide with the thiazolidinone scaffold.<smiles></smiles><smiles>[O][n+]1c(C2SCC(=O)N2c2ccc(Cl)cc2)c[n+](O)c2ccc(F)cc21</smiles><smiles></smiles><smiles></smiles>

As many isonicotinic acid hydrazide derivatives such as isoniazid demonstrated interesting anti-TB activities, an original series of hybrids resulting from the fusion between quinoxaline 1,4-di- $N$-oxide and isoniazid was synthetized; it showed high activity against Mycobacterium tuberculosis, with $\mathrm{IC}_{90}$ ranging from $<1.16$ to $50.60 \mu \mathrm{M}$ versus $0.21 \mu \mathrm{M}$ for isoniazid taken as reference (Figure 13). As isonicotinic hydrazide derivatives can be considered as a prodrug, these new hybrids could act according to the original mechanism of action where the hydrolysis of the compounds would lead to the formation of isoniazid which would act according to its own mechanism of action and of quinoxaline derivatives which would act synergistically with isoniazid. Position 7 unsubstituted or substituted by an electron-withdrawing or electron-releasing group does not differ in activity [59]. 
<smiles>[R6]c1cc2c(cc1[R6])[n+]([O-])c(C(=O)NCc1ccccc1)c(C)[n+]2[O-]</smiles>

49: $\mathrm{R}_{6}: \mathrm{H} ; \mathrm{R}_{7}: \mathrm{H}$

50: $\mathrm{R}_{6}: \mathrm{H} ; \mathrm{R}_{7}: \mathrm{Cl}$

51: $\mathrm{R}_{6}: \mathrm{H} ; \mathrm{R}_{7}: \mathrm{OCH}_{3}$

52: $\mathrm{R}_{6}: \mathrm{H} ; \mathrm{R}_{7}: \mathrm{CH}_{3}$

53: $\mathrm{R}_{6}: \mathrm{CH}_{3} ; \mathrm{R}_{7}: \mathrm{CH}_{3}$

54: $\mathrm{R}_{6}: \mathrm{H} ; \mathrm{R}_{7}: \mathrm{F}$

55: $\mathrm{R}_{6}: \mathrm{H} ; \mathrm{R}_{7}: \mathrm{CF}_{3}$<smiles>[R]c1cc2c(C)c(C=NNC(=O)c3ccncc3)[n+]([O-])[n+]([O-])c2cc1[R]</smiles>

49a: $\mathrm{R}_{6}: \mathrm{H} ; \mathrm{R}_{7}: \mathrm{H}$

50a: $\mathrm{R}_{6}: \mathrm{H} ; \mathrm{R}_{7}: \mathrm{Cl}$

51a: $\mathrm{R}_{6}: \mathrm{H} ; \mathrm{R}_{7}: \mathrm{OCH}_{3}$

52a: $\mathrm{R}_{6}: \mathrm{H} ; \mathrm{R}_{7}: \mathrm{CH}_{3}$

53a: $\mathrm{R}_{6}: \mathrm{CH}_{3} ; \mathrm{R}_{7}: \mathrm{CH}_{3}$

54a: $\mathrm{R}_{6}: \mathrm{H} ; \mathrm{R}_{7}: \mathrm{F}$

55a: $\mathrm{R}_{6}: \mathrm{H} ; \mathrm{R}_{7}: \mathrm{CF}_{3}$

Figure 13. Design of 1,4-di- $N$-oxide quinoxaline-2-ylmethylene isonicotinic acid hydrazide derivatives.

The quinoxaline-2-carboxamide 1,4-di- $\mathrm{N}$-oxide derivatives used as precursors for the synthesis of these new series were also evaluated against Mycobacterium tuberculosis. In these series, molecules substituted with an electron-withdrawing group at position 7 such as $\mathrm{CF}_{3}, \mathrm{Cl}$, or $\mathrm{F}$ on the quinoxaline ring were the most active compounds, with the respective $\mathrm{IC}_{90}$ of $1.07,1.25$, and $4.65 \mu \mathrm{M}$. In order to explore the structural requirements for anti-TB activity, molecular modelling studies were performed on a series of 23 original quinoxaline-2-carboxamide 1,4-di- $\mathrm{N}$-oxide derivatives, with $\mathrm{IC}_{90}$ values ranging from $3.86 \mu \mathrm{g}$ to $100 \mu \mathrm{g}$ [60]. The reliable pharmacophore generated was composed of one aromatic ring, four hydrophobic substituents, three hydrogen acceptors, and one hydrogen donor. The binding mode of these derivatives was similar to that of coumarin in novobiocin, which is known to be an inhibitor of Mycobacterium tuberculosis DNA gyrase active site.

\subsubsection{Other Structures}

In order to develop new antitubercular agents, a series of 33 original quinoxaline-1,4di- $N$-oxide derivatives variously substituted at the $\mathrm{C} 2$ position were synthesized and evaluated [61]. Of these, 17 showed significant activity against Mycobacterium tuberculosis, with the MIC ranging from 0.39 to $6.25 \mu \mathrm{g} / \mathrm{mL}$ and no cytotoxic effects on VERO cells (Table 11). Compounds bearing a thioether linkage and a sterically bulky aromatic group at the terminal side chain on the $\mathrm{C} 2$ position are the best representatives of these original series.

Additionally, the inhibitory effect of methyl, ethyl, isopropyl, and n-propyl esters of quinoxaline 1,4-di- $N$-oxide on Mycobacterium tuberculosis was assessed [62]. Of the 18 original esters of the 1,4-di- $N$-oxide synthesized, eight derivatives showed similar activity to that of isoniazid taken as reference (Table 12).

The steric effect of the ester group at position 7 plays a crucial role in enhancing biological effects. The $\left(\mathrm{CH}_{3}\right)_{2} \mathrm{CH}$ substituent at position 7 enhances antimycobacterial activity. $\mathrm{COOCH}_{3}$ or $\mathrm{COOCH}_{2} \mathrm{CH}_{3}$ attached at position 2 on the quinoxaline ring and $\mathrm{CF}_{3}$ substituent at position 3 also result in increased antimycobacterial activity.

Influence of substitution at positions 2, 3, and 7 was also assessed in a new series of 22 new $\mathrm{N}$-oxide-containing compounds leading to the synthesis of nine quinoxaline 1,4-di- $N$-oxide derivatives [63] (Figure 14). 
Table 11. Chemical structure of some quinoxaline-1,4-di-N-oxide derivatives variously substituted at the C2 position and their MIC values against Mycobacterium tuberculosis.

57<smiles>Cc1c(C(=O)CSc2ccccc2)[n+]([O-])c2ccccc2[n+]1[O-]</smiles><smiles>CC1=C(C(=O)CSc2ccc(C)cc2)N([O])c2ccccc2[N+]1[O]</smiles><smiles>Cc1c(C(=O)CSc2ccc(F)cc2)[n+]([O-])c2ccccc2[n+]1[O-]</smiles>

60<smiles>COc1ccc(SCC(=O)c2c(C)[n+]([O-])c3ccccc3[n+]2[O-])cc1</smiles>

61<smiles>Cc1c(C(=O)CSc2nc[nH]n2)[n+]([O-])c2ccccc2[n+]1[O-]</smiles>

62<smiles>Cc1c(C(=O)CSC2=NC3C=CC=CC3S2)[n+](O)c2ccccc2[n+]1[O-]</smiles> 
Table 12. Chemical structure on methyl, ethyl, isopropyl, and n-propyl esters of quinoxaline 1,4-di- $N$-oxide series and their MIC values against Mycobacterium tuberculosis.

\section{Compound}

63

64

65

66

67

68<smiles>CC(C)OC(=O)c1ccc2c(c1)N([O])C(C(=O)c1cccs1)=C(C(F)(F)F)N2O</smiles><smiles>COC(=O)c1ccc2c(c1)N(O)C(C(=O)c1ccccc1)=C(C(F)(F)F)N2O</smiles><smiles>CC(=O)C1=C(C(F)(F)F)N(O)c2ccc(C(=O)OC(C)C)cc2N1O</smiles><smiles>CC(C)OC(=O)c1ccc2c(c1)N([O])C(C(=O)c1ccc3ccccc3c1)=C(C(F)(F)F)N2[O]</smiles>

69<smiles>CC(C)OC(=O)c1ccc2c(c1)N([O])C(C(=O)C(C)C)=C(C(F)(F)F)N2O</smiles>

70
Microplate Alamar Blue Assay MIC ( $\mu \mathrm{g} / \mathrm{mL})$<smiles>CCCOC(=O)c1ccc2c(c1)N([O])C(C(=O)OC)=C(C)N2O</smiles> 

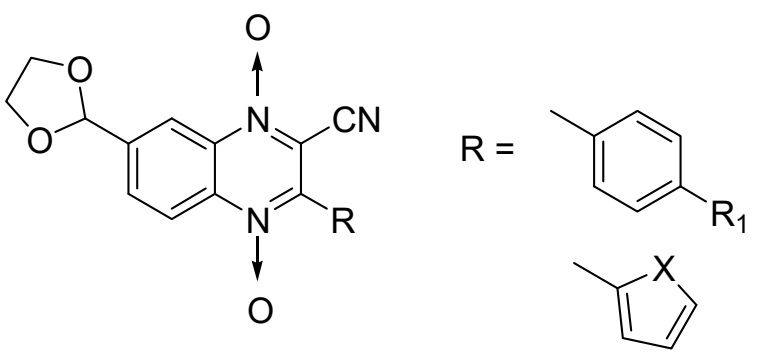

$$
\begin{aligned}
& \mathrm{R}_{1}=\mathrm{H}, \mathrm{CH}_{3}, \mathrm{Cl}, \mathrm{F}, \\
& \mathrm{OCH}_{3}, \mathrm{OCF}_{3} \\
& X=\mathrm{O}, \mathrm{S}
\end{aligned}
$$

Figure 14. Design of the quinoxaline 1,4-di- $N$-oxide derivatives.

For quinoxaline phenyl derivatives, $\mathrm{MIC}_{90}$ values ranged from 12 to $30.8 \mu \mathrm{M}$ versus $0.1 \mu \mathrm{M}$ for the standard drugs isoniazid and rifampicin taken as reference. Antimycobacterial activity was affected by the presence of a para substituent on the phenyl ring: absence of substitution led to the derivative with lowest activity while the derivatives substituted by a methoxy group displayed the highest activity. However, no clear evidence of impact from electron-withdrawing and electron-donating groups was observed. In addition, isosteric substitution of the phenyl ring by furan led to a more active compound, with $\mathrm{MIC}_{90}$ of $5.2 \mu \mathrm{M}$.

\section{Conclusions}

This review highlights the growing interest in the development of compounds bearing a quinoxaline moiety for antimycobacterial treatment, some of these compounds having reached the preclinical evaluation phase. From the published studies, both quinoxaline and quinoxaline-1,4-di- $N$-oxides with a variety of substituents in positions 2, 3, 6, and 7 showed anti-TB activity. From these data, it appears that the quinoxaline moiety represents an interesting scaffold against Mycobacterium tuberculosis. Some structure-activity relationships can be proposed for further investigations on this scaffold. Firstly, it appears that quinoxaline derivatives with the most potent antimycobacterial activity are unsubstituted at positions 1, 4, 5, and 8, although the presence of the pyrrolo substituent at position 1 does not result in a loss of biological activity. Substituents in positions 2 and 3 appear to play an important role in anti-TB activity as the presence of alkynyl derivatives, azide, hydrazone or acylhydrazone, chalcone, azetidinone, thiazolidinone, carboxylic acid substituent leads to significant activity. Various substituents such as thioether linkage, ester, carboxamide, chalcone, ketone, thiazolidinone, or hydrazide at position 2 lead to derivatives with potent antimycobacterial activity in quinoxaline 1,4-di- $N$-oxide series. The presence of a trifluoromethyl or methoxy group at position 3 of the quinoxaline moiety increases the activity. Substitution at positions 6 and 7 is not crucial, but derivatives substituted with ester, halogen, nitro, trifluoromethyl group, chalcone, or heterocycle at these positions exhibited excellent antimycobacterial activity. Hybridization of different pharmacophoric moieties with a quinoxaline nucleus might help to develop an effective molecule for TB treatment. These results warrant further investigations, which may allow identification of novel antitubercular candidates based on this scaffold.

Author Contributions: Conceptualization and methodology, M.M.; formal analysis, M.M. and V.M.; data curation, V.M. and M.M.; writing—original draft preparation, M.M. and V.M.; writing-review and editing, O.K. and P.V.; supervision, P.V. All authors have read and agreed to the published version of the manuscript.

Funding: This research received no external funding.

Institutional Review Board Statement: Not applicable.

Informed Consent Statement: Not applicable.

Conflicts of Interest: The authors declare no conflict of interest. 


\section{References}

1. WHO. Global Tuberculosis Report 2020. Available online: https://www.who.int/publications/i/item/9789240013131 (accessed on 16 April 2021).

2. Keri, R.S.; Pandule, S.S.; Budagumpi, S.; Nagaraja, B.M. Quinoxaline and quinoxaline-1,4-di-N-oxides: An emerging class of antimycobacterials. Arch. Pharm. (Weinh.) 2018, 351, e1700325. [CrossRef]

3. Barthod, L.; Lopez, J.G.; Curti, C.; Bornet, C.; Roche, M.; Montana, M.; Vanelle, P. News on therapeutic management of MDR-tuberculosis: A literature review. J. Chemother. 2018, 30, 1-15. [CrossRef]

4. Shagufta; Ahmad, I. An insight into the therapeutic potential of quinazoline derivatives as anticancer agents. MedChemCom 2017, 8, 871-885. [CrossRef]

5. Kalaria, P.N.; Karad, S.C.; Raval, D.K. A review on diverse heterocyclic compounds as the privileged scaffolds in antimalarial drug discovery. Eur. J. Med. Chem. 2018, 158, 917-936. [CrossRef]

6. Kerru, N.; Gummidi, L.; Maddila, S.; Gangu, K.K.; Jonnalagadda, S.B. A Review on Recent Advances in Nitrogen-Containing Molecules and Their Biological Applications. Molecules 2020, 25, 1909. [CrossRef] [PubMed]

7. Heravi, M.M.; Zadsirjan, V. Prescribed drugs containing nitrogen heterocycles: An overview. RCS Adv. 2020, 10, 44247-44311.

8. Deepika, Y.; Nath, P.S.; Sachin, K.; Shewta, S. Biological activity of quinoxaline derivatives. Int. J. Curr. Pharm. Res. 2011, 2, 33-46.

9. Montana, M.; Montero, V.; Khoumeri, O.; Vanelle, P. Quinoxaline Derivatives as Antiviral Agents: A Systematic Review. Molecules 2020, 25, 2784. [CrossRef] [PubMed]

10. Montana, M.; Mathias, F.; Terme, T.; Vanelle, P. Antitumoral activity of quinoxaline derivatives: A systematic review. Eur. J. Med. Chem. 2019, 163, 136-147. [CrossRef]

11. Barea, C.; Pabón, A.; Pérez-Silanes, S.; Galiano, S.; Gonzalez, G.; Monge, A.; Deharo, E.; Aldana, I. New Amide Derivatives of Quinoxaline 1,4-di-N-Oxide with Leishmanicidal and Antiplasmodial Activities. Molecules 2013, 18, 4718-4727. [CrossRef]

12. González, M.; Cerecetto, H. Quinoxaline derivatives: A patent review (2006-present). Expert Opin. Ther. Pat. 2012, 22, 1289-1302. [CrossRef] [PubMed]

13. Zanetti, S.; Sechi, L.A.; Molicotti, P.; Cannas, S.; Bua, A.; Deriu, A.; Carta, A.; Paglietti, G. In vitro activity of new quinoxalin 1,4-dioxide derivatives against strains of Mycobacterium tuberculosis and other mycobacteria. Int. J. Antimicrob. Agents 2005, 25, 179-181. [CrossRef]

14. Ortega, M.A.; Montoya, M.E.; Jaso, A.; Zarranz, B.; Tirapu, I.; Aldana, I.; Monge, A. Antimycobacterial activity of new quinoxaline2-carbonitrile and quinoxaline-2-carbonitrile 1,4-di-N-oxide derivatives. Pharmazie 2001, 56, 205-207. [CrossRef]

15. Villar, R.; Vicente, E.; Solano, B.; Perez-Silanes, S.; Aldana, I.; Maddry, J.A.; Lenaerts, A.J.; Franzblau, S.G.; Cho, S.H.; Monge, A.; et al. In vitro and in vivo antimycobacterial activities of ketone and amide derivatives of quinoxaline 1,4 -di- $\mathrm{N}$-oxide. J. Antimicrob. Chemother. 2008, 62, 547-554. [CrossRef] [PubMed]

16. Crawford, P.W.; Scamehorn, R.G.; Hollstein, U.; Ryan, M.D.; Kovacic, P. Cyclic voltammetry of phenazines and quinoxalines including mono- and di-N-oxides. Relation to structure and antimicrobial activity. Chem. Biol. Interact. 1986, 60, 67. [CrossRef]

17. Chowdhury, G.; Kotandeniya, D.; Daniels, J.S.; Barnes, C.L.; Gates, K.S. Enzyme-activated, hypoxia-selective DNA damage by 3-amino-2-quinoxalinecarbonitrile 1,4-di-N-oxide. Chem. Res. Toxicol. 2004, 17, 1399-1405. [CrossRef] [PubMed]

18. Moher, D.; Liberati, A.; Tetzlaff, J.; Altman, D.G. The PRISMA Group Preferred Reporting Items for Systematic Reviews and Meta-Analyses: The PRISMA Statement. PLoS Med. 2009, 3, 123-130.

19. Cheeseman, G.W.H.; Cookson, R.F. Condensed Pyrazines. In The Chemistry of Heterocyclic Compounds; Weissberger, A., Taylor, E.C., Eds.; John Wiley \& Sons, Inc.: New York, NY, USA, 1979; Volume 35, pp. 78-111.

20. Pereira, J.A.; Pessoa, A.M.; Cordeiro, M.N.D.S.; Fernandes, R.; Prudencio, C.; Noronha, J.P.; Vieira, M. Quinoxaline, its derivative and applications: A state of the art review. Eur. J. Med. Chem. 2015, 97, 664-672. [CrossRef] [PubMed]

21. Brown, D.J.; Ellman, J.A. The Chemistry of Heterocyclic Compounds; Wiley: New York, NY, USA, 2004.

22. Aparicio, D.; Attanasi, O.A.; Filippone, P.; Ignacio, R.; Lillini, S.; Mantellini, F.; Palacios, F.; De Los Santos, J.M. Straightforward access to pyrazines, piperazinones, and quinoxalines by reactions of 1,2-diaza-1,3-butadienes with 1,2-diamines under solution, solvent-free, or solid-phase conditions. J. Org. Chem. 2006, 71, 5897-5905. [CrossRef] [PubMed]

23. Cai, J.J.; Zou, J.P.; Pan, X.Q.; Zhang, W. Gallium triflate catalyzed synthesis of quinoxaline derivatives. Tetrahedron Lett. 2008, 49, 7386-7390. [CrossRef]

24. Antoniotti, S.; Dunach, E. Direct and catalytic synthesis of quinoxaline derivatives from epoxides and ene-1,2-diamines. Tetrahedron Lett. 2002, 43, 3971-3973. [CrossRef]

25. Kumar, K.; Mudshinge, S.R.; Goyal, S.; Gangar, M.; Nair, V.A. A catalyst free, one pot approach for the synthesis of quinoxaline derivatives via oxidative cyclisation of 1,2-diamines and phenacyl bromides. Tetrahedron Lett. 2015, 56, 1266-1271. [CrossRef]

26. Gris, J.; Glisoni, R.; Fabian, L.; Fernandez, B.; Moglioni, A.G. Synthesis of potential chemotherapic quinoxalinone derivatives by biocatalysis or microwave-assisted Hinserg reaction. Tetrahedron Lett. 2008, 49, 1053-1056. [CrossRef]

27. Rostamizadeh, S.; Jafari, S. The synthesis of quinoxalines under microwave irradiation. Indian J. Heterocycl. Chem. 2001, 10, 303-304.

28. Shaabani, A.; Maleki, A. Green and efficient synthesis of quinoxaline derivatives via ceric ammonium nitrate promoted and in situ aerobic oxidation of alpha-hydroxy ketones and alpha-keto oximes in aqueous media. Chem. Pharm. Bull. 2008, 56, 79-81. [CrossRef] 
29. Thakuria, H.; Das, G. One-pot efficient green synthesis of 1,4-dihydroquinoxaline-2,3-dione derivatives. J. Chem. Sci. 2006, 118, 425-428. [CrossRef]

30. Kumar, S.; Kumar, N.; Drabu, S. Synthesis of benzo[g]quinoxaline-5,10-dione based pyridine derivatives and their antimycobacterial activity. Orient. J. Chem. 2017, 33, 821-828. [CrossRef]

31. Kumar, S.; Kumar, N.; Drabu, S. Synthesis of benzo[g]quinoxaline-5,10-dione based pyrazoline derivatives and their antimycobacterial activity. Int. J. Pharm. Sci. Res. 2018, 9, 498-508.

32. Kumar, S.; Kumar, N.; Drabu, S. Synthesis and in vitro antimycobacterial activity of 7-[3-(substituted) phenylprop-2-enoyl]-2,3diphenyl-5H,10H-benzo[g]quinoxaline-5,10-diones. Indian J. Heterocycl. Chem. 2017, 27, 25-31.

33. Guillon, J.; Reynolds, R.C.; Leger, J.M.; Guie, M.A.; Massip, S.; Dallemagne, P.; Jarry, C. Synthesis and preliminary in vitro evaluation of antimycobacterial activity of new pyrrolo[1,2-a]quinoxaline-carboxylic acid hydrazide derivatives. J. Enzym. Inhib. Med. Chem. 2004, 19, 489-495. [CrossRef]

34. Wang, T.; Tang, Y.; Yang, Y.; An, Q.; Sang, Z.; Yang, T.; Liu, P.; Zhang, T.; Deng, Y.; Luo, Y. Discovery of novel tuberculosis agents with pyrrolo[1,2-a]quinoxaline based scaffold. Bioorg. Med. Chem. Lett. 2018, 28, 2084-2090. [CrossRef]

35. Makane, V.B.; Vamshi Krishna, E.; Karale, U.B.; Babar, D.A.; Kalari, S.; Rekha, E.M.; Shukla, M.; Kaul, G.; Sriram, D.; Chopra, S.; et al. Synthesis of novel 4,5-dihydropyrrolo[1,2-a]quinoxalines, pyrrolo[1,2-a]quinoxalin]-2-ones and their antituberculosis and anticancer activity. Arch. Pharm. (Weinh.) 2020, 353, e2000192. [CrossRef] [PubMed]

36. Vijaykumar, M.M.; Nagaraja, T.S.; Shameer, H.; Jayachandran, E.; Sreenivasa, G.M. N-substituted-3-chloro-2-azetidinones: Synthesis and characterization of new novel anti-inflammatory agents. J. Pharm. Sci. Res. 2009, 1, 83-92.

37. Sandip, J.; Mahesh, P.; Veeresh, M.; Pradeepkumar, R.; Shivalingarao, M.; Satyanarayana, D.; Mangala, G. Synthesis and antimycobacterial activity of a novel series of isonicotinyl hydrazide derivatives. Arch. Pharm. Chem. Life Sci. 2009, 342, 723-731.

38. Amit, V.; Shailendra, K.S. 4-Thiazolidinone-A biologically active scaffold. Eur. J. Med. Chem. 2008, 43, 897-905.

39. Puratchikody, A.; Natarajan, R.; Jayapal, M.; Doble, M. Synthesis, in vitro antitubercular activity and 3D-QSAR of novel quinoxaline derivatives. Chem. Biol. Drug Des. 2011, 78, 988-998. [CrossRef] [PubMed]

40. Nogueira, T.C.M.; dos Santos Cruz, L.; Lourenço, M.C.; de Souza, M.V.N. Design, synthesis and anti-tuberculosis activity of hydrazones and $n$-acylhydrazones containing vitamin B6 and different heteroaromatic nucleus. Lett. Drug Des. Discov. 2019, 16, 792-798. [CrossRef]

41. Calvaresi, E.C.; Hergenrother, P.J. Glucose conjugation for the specific targeting and treatment of cancer. Chem. Sci. 2013, 4, 2319-2333. [CrossRef]

42. Xavier, N.M.; Goulart, M.; Neves, A.; Justino, J.; Chambert, S.; Rauter, A.P.; Queneau, Y. Synthesis of sugars embodying conjugated carbonyl systems and related triazole derivatives from carboxymethyl glycoside lactones. Evaluation of their antimicrobial activity and toxicity. Bioorg. Chem. 2011, 19, 926-938. [CrossRef]

43. Peraman, R.; Kuppusamy, R.; Killi, S.K.; Reddy, Y.P. New Conjugates of Quinoxaline as Potent Antitubercular and Antibacterial Agents. Int. J. Med. Chem. 2016, 2016, 6471352. [CrossRef] [PubMed]

44. Gomes, M.N.; Braga, R.C.; Grzelak, E.M.; Neves, B.J.; Muratov, E.N.; Ma, R.; Klein, L.L.; Cho, S.; Oliveira, G.R.; Franzblau, S.G.; et al. QSAR-driven design, synthesis and discovery of potent and selective chalcone derivatives with antitubercular activity. Eur. J. Med. Chem. 2017, 137, 126-138. [CrossRef] [PubMed]

45. Lin, Y.M.; Zhou, Y.; Flavin, M.; Zhou, L.M.; Nie, W.; Chen, F.C. Chalcones and flavonoids as anti-tuberculosis agents. Bioorg. Med. Chem. 2002, 10, 2795-2802. [CrossRef]

46. Desai, V.G.; Desai, S.R.; Gaonkar, S.N.; Palyekar, U.; Joshi, S.; Dixit, S. Novel quinoxalinyl chalcone hybrid scaffolds as enoyl ACP reductase inhibitors: Synthesis, molecular docking and biological evaluation. Bioorg. Med. Chem. Lett. 2017, 27, $2174-2180$. [CrossRef] [PubMed]

47. Muradás, T.C.; Abbadi, B.L.; Villela, A.D.; Macchi, F.S.; Bergo, P.F.; de Freitas, T.F.; Sperotto, N.; Timmers, L.; Norberto de Souza, O.; Picada, J.N.; et al. Pre-clinical evaluation of quinoxaline-derived chalcones in tuberculosis. PLoS ONE 2018, 13, e0202568.

48. Peraman, R.; Varma, R.V.; Reddy, Y.P. Re-engineering nalidixic acid's chemical scaffold: A step towards the development of novel anti-tubercular and anti-bacterial leads for resistant pathogens. Bioorg. Med. Chem. Lett. 2015, 25, 4314-4319. [CrossRef] [PubMed]

49. Achutha, L.; Parameshwar, R.; Madhava Reddy, B.; Harinadha Babu, V. Microwave-Assisted Synthesis of Some QuinoxalineIncorporated Schiff Bases and Their Biological Evaluation. J. Chem. 2013, 2013, 578438. [CrossRef]

50. Kumar, R.R.; Perumal, S.; Senthilkumar, P.; Yogeeswari, P.; Sriram, D. Discovery of antimycobacterial spiro-piperidin-4-ones: An atom economic, stereoselective synthesis, and biological intervention. J. Med. Chem. 2008, 51, 5731-5735. [CrossRef]

51. Prasanna, P.; Balamurugan, K.; Perumal, S.; Yogeeswari, P.; Sriram, D. A regio- and stereoselective 1,3-dipolar cycloaddition for the synthesis of novel spiro-pyrrolothiazolyloxindoles and their antitubercular evaluation. Eur. J. Med. Chem. 2010, 45, 5653-5661. [CrossRef]

52. Arumugam, N.; Almansour, A.I.; Suresh Kumar, R.; Ibrahim Alaqeel, S.; Siva Krishna, V.; Sriram, D. Anti-tubercular activity of novel class of spiropyrrolidine tethered indenoquinoxaline heterocyclic hybrids. Bioorg. Chem. 2020, 99, 103799. [CrossRef]

53. Raphoko, L.A.; Lekgau, K.; Lebepe, C.M.; Leboho, T.C.; Matsebatlela, T.M.; Nxumalo, W. Synthesis of novel quinoxaline-alkynyl derivatives and their anti-Mycobacterium tuberculosis activity. Bioorg. Med. Chem. Lett. 2021, 35, 127784. [CrossRef]

54. Neres, J.; Hartkoorn, R.C.; Chiarelli, L.R.; Gadupudi, R.; Pasca, M.R.; Mori, G.; Venturelli, A.; Savina, S.; Makarov, V.; Kolly, G.S.; et al. 2-Carboxyquinoxalines kill mycobacterium tuberculosis through noncovalent inhibition of DprE1. ACS Chem. Biol. 2015, 10, 705-714. [CrossRef] 
55. Xu, Y.; Wu, F.; Yao, Z.; Zhang, M.; Jiang, S. Synthesis of quinoxaline 1,4-di-N-oxide analogues and crystal structure of 2carbomethoxy-3-hydroxyquinoxaline-di-N-oxide. Molecules 2011, 16, 6894-6901. [CrossRef]

56. Srinivasarao, S.; Nandikolla, A.; Suresh, A.; Ewa, A.K.; Głogowska, A.; Ghosh, B.; Kumar, B.K.; Murugesan, S.; Pulya, S.; Aggarwal, H.; et al. Discovery of 1,2,3-triazole based quinoxaline-1,4-di- $N$-oxide derivatives as potential anti-tubercular agents. Bioorg. Med. Chem. 2020, 100, 103955. [CrossRef]

57. Santivañez-Veliz, M.; Pérez-Silanes, S.; Torres, E.; Moreno-Viguri, E. Design and synthesis of novel quinoxaline derivatives as potential candidates for treatment of multidrug-resistant and latent tuberculosis. Bioorg. Med. Chem. Lett. 2016, 26, $2188-2193$. [CrossRef]

58. Zhang, H.; Zhang, J.; Qu, W.; Xie, S.; Huang, L.; Chen, D.; Tao, Y.; Liu, Z.; Pan, Y.; Yuan, Z. Design, Synthesis, and Biological Evaluation of Novel Thiazolidinone-Containing Quinoxaline-1,4-di- $\mathrm{N}$-oxides as Antimycobacterial and Antifungal Agents. Front. Chem. 2020, 8, 598. [CrossRef]

59. Torres, E.; Moreno, E.; Ancizu, S.; Barea, C.; Galiano, S.; Aldana, I.; Monge, A.; Pérez-Silanes, S. New 1,4-di-N-oxide-quinoxaline2-ylmethylene isonicotinic acid hydrazide derivatives as anti-Mycobacterium tuberculosis agents. Bioorg. Med. Chem. Lett. 2011, 21, 3699-3703. [CrossRef]

60. Radwan, A.A.; Abdel-Mageed, W.M. In Silico Studies of Quinoxaline-2-Carboxamide 1,4-di-N-Oxide Derivatives as Antimycobacterial Agents. Molecules 2014, 19, 2247-2260. [CrossRef]

61. Pan, Y.; Li, P.; Xie, S.; Tao, Y.; Chen, D.; Dai, M.; Hao, H.; Huang, L.; Wang, Y.; Wang, L.; et al. Synthesis, 3D-QSAR analysis and biological evaluation of quinoxaline 1,4-di-N-oxide derivatives as antituberculosis agents. Bioorg. Med. Chem. Lett. 2016, 26, 4146-4153. [CrossRef]

62. Palos, I.; Luna-Herrera, J.; Lara-Ramírez, E.E.; Loera-Piedra, A.; Fernández-Ramírez, E.; Aguilera-Arreola, M.G.; Paz-González, A.D.; Monge, A.; Wan, B.; Franzblau, S.; et al. Anti-Mycobacterium tuberculosis Activity of Esters of Quinoxaline 1,4-Di- $\mathrm{N}$-Oxide. Molecules 2018, 23, 1453. [CrossRef]

63. Dos Santos Fernandes, G.F.; de Souza, P.C.; Moreno-Viguri, E.; Santivañez-Veliz, M.; Paucar, R.; Pérez-Silanes, S.; Chegaev, K.; Guglielmo, S.; Lazzarato, L.; Fruttero, R.; et al. Design, Synthesis, and Characterization of N-Oxide-Containing Heterocycles with in Vivo Sterilizing Antitubercular Activity. J. Med. Chem. 2017, 60, 8647-8660. [CrossRef] 